\title{
Carbon fluxes in a coastal area of northern Portugal
}

\author{
Rogério Carvalho $^{* 1}$ and Pedro Duarte ${ }^{1,2}$
}

${ }^{1}$ Global Change, Energy, Environment and Bioengineering R\&D Unit (CIAGEB), Faculdade de Ciência e Tecnologia, Universidade Fernando Pessoa, Praça 9 de Abril, 349, 4249-004 Porto, Portugal.

${ }^{2}$ Interdisciplinary Centre for Marine and Environmental Research-CIIMAR, Rua dos Bragas, 289, 4050-123 Porto, Portugal.

* Corresponding author: carvalho@ufp.edu.pt

Received: 30/10/12 Accepted: 26/7/13

\begin{abstract}
Carbon fluxes in a coastal area of northern Portugal

Estuaries have been the focus of several studies of the carbon biogeochemical cycle. Despite their small area compared with other coastal regions, estuaries may play a significant role in the carbon biogeochemical cycle due to their intense biogeochemical activity resulting from river and anthropogenic inputs of organic and inorganic matter. Most of these studies suggest that estuaries are sources of carbon inputs to the atmosphere. This study describes a study conducted in the Ave estuary (northern Portugal) in summer 2011 and winter 2012 to quantify the air-water $\mathrm{CO}_{2}$ fluxes. Surface waters were always oversaturated in $\mathrm{CO}_{2}$ relative to the atmosphere. $\mathrm{CO}_{2}$ partial pressure ranged from $\approx 689$ to $\approx 1111 \mu$ atm in summer during the flood and the ebb, respectively, whereas winter values ranged from $\approx 767$ to $\approx 1021 \mu$ atm during the ebb and the flood, respectively. These results suggest that the Ave estuary releases $\mathrm{CO}_{2}$ to the atmosphere at rates ranging from 6 to $34 \mathrm{mmol} \mathrm{C}$ $\mathrm{m}^{-2} \mathrm{~d}^{-1}$, in summer and from 13 to $40 \mathrm{mmol} \mathrm{C} \mathrm{m} \mathrm{d}^{-1}$ in winter. These values are lower than estimates for other Portuguese estuaries, such as the Tagus, Douro or Sado.
\end{abstract}

Key words: Estuaries, $\mathrm{CO}_{2}$, carbon cycle, source, sink.

\section{RESUMEN}

\section{Los flujos de carbono en una zona costera del norte de Portugal}

Los estuarios han sido objeto de varios estudios sobre el ciclo biogeoquímico del carbono. A pesar de su reducida superficie, en comparación con otras regiones costeras, los estuarios pueden jugar un papel importante en el ciclo biogeoquímico del carbono debido a su intensa actividad biogeoquímica como resultado de las entradas de carbono por el río y de las emisiones antropogénicas de materia orgánica e inorgánica. La mayoría de estos estudios sugieren que los estuarios son fuentes de carbono a la atmósfera. Este trabajo describe un estudio llevado a cabo en el estuario del Ave (norte de Portugal) en el verano de 2011 e invierno 2012, donde los flujos aire-agua de $\mathrm{CO}_{2}$ fueron cuantificados. Las aguas superficiales estaban sobresaturadas siempre en $\mathrm{CO}_{2}$ con respecto a la atmósfera. La presión parcial de $\mathrm{CO}_{2}$ varió de $\approx 689$ a $\approx 1111 \mu$ atm en verano, durante el flujo y reflujo, respectivamente, mientras que los valores de invierno van desde $\approx 767$ a $\approx 1021 \mu a t m$, durante el reflujo y flujo, respectivamente. Estos resultados sugieren que el estuario del Ave libera $\mathrm{CO}_{2}$ a la atmósfera con una tasa media entre 6 y $34 \mathrm{mmol} \mathrm{C} \mathrm{m}^{-2} \mathrm{~d}^{-1}$ en verano, y entre 13 y $40 \mathrm{mmol} \mathrm{C} \mathrm{m}^{-2} \mathrm{~d}^{-1}$ en invierno. Estos valores son más bajos que los obtenidos para otros estuarios portugueses como el Tajo, Duero y Sado.

Palabras clave: Estuarios, $\mathrm{CO}_{2}$, ciclo del carbono, fuente, sumidero. 


\section{INTRODUCTION}

The $\mathrm{CO}_{2}$ fluxes in the coastal ocean are poorly known. The coastal ocean is the portion of the global ocean where physical, biological and biogeochemical processes are directly affected by land drainage (Gazeau et al., 2004), limited offshore by the ocean margin, corresponding to the abrupt bathymetric change that occurs between the shelf and the slope at an average depth of 130 m (Gattuso et al., 1998; Wollast, 1998). Estimates of the uptake of $\mathrm{CO}_{2}$ in this zone vary significantly (Orr et al., 2001; Thomas et al., 2001; Borges, 2005; Borges et al., 2005; Bozec et al., 2005; Orr et al., 2005; Chen \& Borges, 2009; Laruelle et al., 2010). Coastal zones may have a disproportionately high contribution to the ocean storage of $\mathrm{CO}_{2}$ (Thomas et al., 2004) via a mechanism called the "continental shelf pump" (Tsunogai et al., 1999). However, this hypothesis deserves further investigation due to the very low spatial and temporal resolution of available data on $\mathrm{CO}_{2}$ fluxes (Borges \& Frankignoulle, 2002). Furthermore, it is expected that these fluxes are influenced by upwelling, land drainage, sea surface warming and $\mathrm{pH}$ decreasing trends (Borges, 2011). The continental shelf pump hypothesis has been a topic of considerable debate (e.g., Cai \& Dai, 2004; Thomas et al., 2004, 2008).

Abril \& Borges (2004) provide a summary of estuarine definitions, ranging from the classic definition of Pritchard (1967) as "semi-enclosed coastal bodies of water that have a free connection with the open sea and within which sea water is measurably diluted with fresh water derived from land drainage" to the more complete definition of Perillo (1995) that specifies the upstream limit of estuaries as the limit of tidal influence and refer some of its biological aspects, as the presence of euryhaline species. These dynamic systems and the coastal seas play an important role in the global carbon cycle (Mackenzie et al., 2004) despite their small area compared to the global ocean (Borges, 2005). In estuaries and coastal zones, high fluxes of $\mathrm{CO}_{2}$ between the surface water and the atmosphere are expected due to their high biogeochemical activity (Abril et al., 2000). Globally, the surface area of estuaries is approximately 20 times smaller than the surface area of continental shelves. However, the air-water fluxes of $\mathrm{CO}_{2}$ in temperate estuaries are approximately two orders of magnitude higher than those over temperate continental shelves (Borges et al., 2004a).

Ketchum (1983, cit. in Gazeau et al., 2004) states that estuaries are extremely dynamic systems; they are usually characterised by strong physico-chemical gradients, enhanced biological activity and intense sedimentation and resuspension because they receive large amounts of inorganic nutrients (nitrogen, phosphorus and silica), organic matter and suspended particles. Estuarine ecosystems have a net heterotrophic metabolism, consuming more organic carbon than the autochthonous gross primary production (Borges, 2011).

Recent studies suggest that estuaries are significant sources of $\mathrm{CO}_{2}$ to the atmosphere, with carbon dioxide partial pressure $\left(\mathrm{pCO}_{2}\right)$ varying from 400 to $9500 \mu \mathrm{atm}$ (Frankignoulle et al., 1998; Borges et al., 2003; Abril \& Borges, 2004; Wang \& Cai, 2004, Borges, 2005; Borges et al., 2005, Laruelle et al., 2010; Borges \& Abril, 2011). It is argued that this source role (Borges 2005; Borges et al., 2005) can be counterbalanced by the continental shelf $\mathrm{CO}_{2}$ sink (Tsunogai et al., 1999; Borges et al., 2005; Cai et al., 2006). However, reported air-water $\mathrm{CO}_{2}$ fluxes can lead to biased interpretations due to insufficient spatial or temporal coverage (Borges, 2011).

Frankignoulle et al. (1998), Borges (2005 and 2011) and Borges et al. (2005) state that most estuaries where $\mathrm{CO}_{2}$ fluxes have been evaluated are macrotidal estuaries, whereas data on microtidal and mesotidal estuaries (and other estuarine environments) are scarce. Despite this lack of data, it is accepted that microtidal systems are usually highly stratified and are lower sources of $\mathrm{CO}_{2}$ to the atmosphere than macrotidal systems, which are usually permanently or partly well mixed (Koné et al., 2009; Borges, 2011; Borges \& Abril, 2011).

Highly variable organic carbon production and degradation are expected in estuaries relative to other coastal environments, with effects on chlorophyll $a(\mathrm{Chl} a)$, dissolved organic carbon 


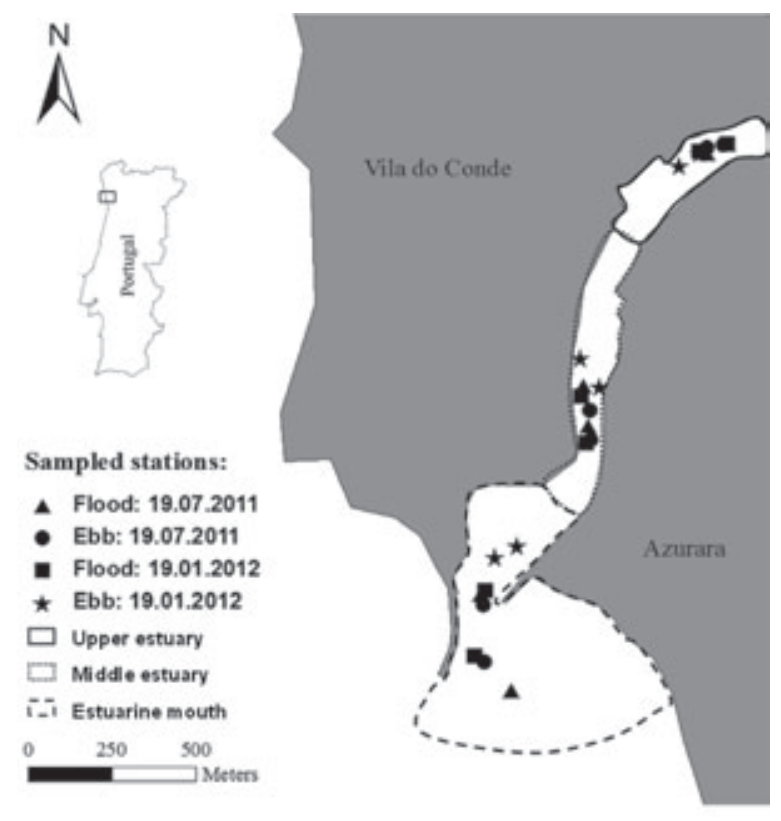

Figure 1. The study site and sampling stations. Área de estudio y estaciones de muestreo.

(DOC) and oxygen saturation $\left(\% \mathrm{O}_{2}\right)$ (Borges \& Abril, 2011) leading to high $\mathrm{pCO}_{2}$ variability. Carbon enters estuaries in various forms: dissolved inorganic and organic (DIC and DOC, respectively) or particulate inorganic and organic (PIC and POC, respectively) (Meybeck, 1993). All these forms contribute to the source/sink $\mathrm{CO}_{2}$ role of estuaries.

To tackle the temporal and spatial lack of data on microtidal estuaries, the main objective of this study was to evaluate $\mathrm{CO}_{2}$ transfer between the water and the atmosphere of the Ave estuary as a function of the season, distance from the sea and tide based on the $\mathrm{CO}_{2}$ saturation level of the surface waters.

\section{METHODS}

\section{Study area}

This study was conducted in the Ave estuary, a small estuary with a surface area of approximately $0.28 \mathrm{~km}^{2}$ located in northwestern Portugal $\left(41^{\circ} 34^{\prime} \mathrm{N}, 08^{\circ} 74^{\prime} \mathrm{W}\right)$ (Fig. 1). Its upstream limit is marked by a dam near the N13 road bridge. The Ave estuary is approximately $1.5 \mathrm{~km}$ in length, with a minimum width of $75 \mathrm{~m}$ and a maximum width of $200 \mathrm{~m}$. The maximum depth of this estuary during the flood is approximately $9 \mathrm{~m}$. The tidal regime is semidiurnal, with a period of c.a. $12 \mathrm{~h} 33 \mathrm{~min}$ and a tidal range from $\approx 1 \mathrm{~m}$ to 3 m (Hidrográfico, 2011) (Table 1).

The hydrographic conditions of the estuary are essentially determined by river discharges, which show marked seasonal variation, as well as by the intrusion of saline water from the Atlantic Ocean. The intrusion of freshwater is mainly carried out by the Ave river discharge, ranging between approximately 8 and $45 \mathrm{~m}^{3}$ $\mathrm{s}^{-1}$ (Snirh, 2011) (Table 1). The average current speed in summer is approximately $0.3 \mathrm{~m} \mathrm{~s}^{-1}$, with maximum values of $1.2 \mathrm{~m} \mathrm{~s}^{-1}$ at the inlet. The relatively low flow in the Ave estuary allows the formation of a thermocline and a halocline, typical of a salt-wedge estuary. The prevailing winds are from the south and southwest in winter and from the northwest in spring and summer (Carvalho et al., 2011).

\section{Sampling strategy}

Data for this study were obtained from two cruises conducted in July 2011 and January 2012. A total of 24 stations were sampled in the estuary (Fig. 1). The study area was divided into three sections: lower (mouth), middle and upper (near the upper limit of the estuary) to test for differences in the $\mathrm{CO}_{2}$ source/sink processes along the estuary. During each sampling survey, a total of six sites were sampled during the ebb, and another six sites were sampled during the flood. Therefore, two replicate stations were sampled in each of the mentioned three zones.

\section{In situ measurements and sampling}

Temperature, depth, salinity, dissolved oxygen, $\mathrm{pH}$, chlorophyll $a$ and Photosynthetically Active Radiation (PAR) were determined in situ with a conductivity-temperature-depth device (CTD) (Sea and Sun CTD 90M Multiparameter Memory Probe). Samples were collected at all sites with a 
Van Dorn bottle at the surface and at the bottom to analyse suspended particulate matter (SPM) and total alkalinity (TA).

\section{Atmospheric and meteorological data}

Atmospheric $\mathrm{CO}_{2}$ concentration data and air temperatures were collected in situ using an air $\mathrm{CO}_{2}$ sensor (Kimo Instruments) for the winter sampling. In summer, atmospheric $\mathrm{CO}_{2}$ data were obtained from the Terceira Island reference station (Azores, Portugal, 38 46' N $\left.27^{\circ} 23^{\prime} \mathrm{W}\right)$. This station is a component of the network of the National Oceanic and Atmospheric Administration (NOAA)/Climate Monitoring and Diagnostics Laboratory/Carbon Cycle Greenhouse Gases Group (CarbonTracker 2011, http://carbontracker.noaa.gov). Wind speed and direction data were obtained from a public database (www.windguru.cz/pt). The atmospheric $\mathrm{CO}_{2}$ concentrations data, in winter, collected with a $\mathrm{CO}_{2}$ sensor, are in the range $397 \pm 7 \mu$ atm, consistent with data obtained from the Terceira Island reference station (391.6 $\mu \mathrm{atm}$, latest available values from January 2010).

\section{Laboratory analysis}

SPM was determined gravimetrically following the standard procedures described previously (e.g., Filgueira et al., 2009). The samples were filtered with previously treated Whatman GF/F filters ( $2 \mathrm{~h}$ at $450{ }^{\circ} \mathrm{C}$ and weighed). After filtration, the filters with the particulate material were again weighed after drying at $70^{\circ} \mathrm{C}$ for $24 \mathrm{~h}$ in an oven.

Samples for TA determinations were filtered through Whatman GF/F filters $(0.7 \mu \mathrm{m})$ and titrated with $\mathrm{HCl}(\sim 0.25 \mathrm{M} \mathrm{HCl}$ in a solution of $0.45 \mathrm{M} \mathrm{NaCl}$ ) past the endpoint of 4.5 (Dickson et al., 2007) with an accuracy of $\pm 25 \mu \mathrm{mol} \mathrm{kg}{ }^{-1}$.

\section{Calculations}

DIC and $\mathrm{pCO}_{2}$ in water were estimated from in situ temperature, $\mathrm{pH}$ and TA using the carbonic acid dissociation constants given by Millero et al. (2006) and the $\mathrm{CO}_{2}$ solubility coefficient of Weiss (1974) (Abril et al., 2000; Borges et al., 2004a).
Errors associated with $\mathrm{pCO}_{2}$ calculations were estimated to be $\pm 30 \mu \mathrm{atm}$ (accumulated errors on TA and $\mathrm{pH})$. The air-water $\mathrm{CO}_{2}$ fluxes $\left(\mathrm{CO}_{2}\right.$ Flux $)$ were computed according to the equation

$$
\mathrm{CO}_{2} \text { Flux }=k \cdot K_{0} \cdot \Delta \mathrm{pCO}_{2},
$$

where $k$ is the gas transfer velocity, $K_{0}$ is the solubility coefficient of $\mathrm{CO}_{2}$ (a function of temperature and salinity) and $\Delta \mathrm{pCO}_{2}$ is the air-water gradient of $\mathrm{pCO}_{2}$. A positive $\mathrm{CO}_{2}$ flux indicates a transfer of $\mathrm{CO}_{2}$ from the water to the atmosphere.

The gas transfer velocity plays an important role in the $\mathrm{CO}_{2}$ flux equation. At the air-water interface, turbulence is the most important process controlling $\mathrm{k}$ (Borges et al., 2004b). In the open ocean, the gas transfer velocity of $\mathrm{CO}_{2}$ is usually parameterised as a function of wind speed because wind stress is the main generator of surface turbulence in these systems (Borges et al., 2004b, Abril et al., 2009). In estuaries, $\mathrm{k}$ is highly variable over time and space and is in?uenced by local meteorological and hydrological conditions (Kremer et al., 2003; Borges et al., 2004a, Abril et al., 2009). The value of $k$ tends to be greater in estuaries than in the open ocean due to the greater current speeds in the estuaries. The gas transfer velocity of $\mathrm{CO}_{2}$ increases more rapidly with wind speed in large estuaries than in small estuaries due to a fetch effect (Marino \& Howarth, 1993; Zappa et al., 2003, 2007; Borges et al., 2004a, b). Abril et al. (2009) proposed an equation for $k$ that depends on wind and current velocity, estuarine surface area and the concentration of total suspended solids. Recently, Ho et al. (2011) suggested that a parameterisation between wind speed and gas exchange developed for the ocean is able to predict gas exchange in tidal rivers with high accuracy. The choice of a particular value for $\mathrm{k}$ will, therefore, affect the overall estimates of gas transfer across the air-water interface. In this study, $k$ was not determined in situ but was calculated with four different formulations: (1) Carini et al. (1996) (hereafter referred as $\left.k_{C 96}\right)$, (2) Raymond et al. (2000) (hereafter referred as $k_{R 00}$ ), (3) Borges et al. (2004b) (hereafter referred as $\left.k_{B 04}\right)$ and (4) Abril et al. (2009) (hereafter referred as $k_{A 09}$ ). 
Surface
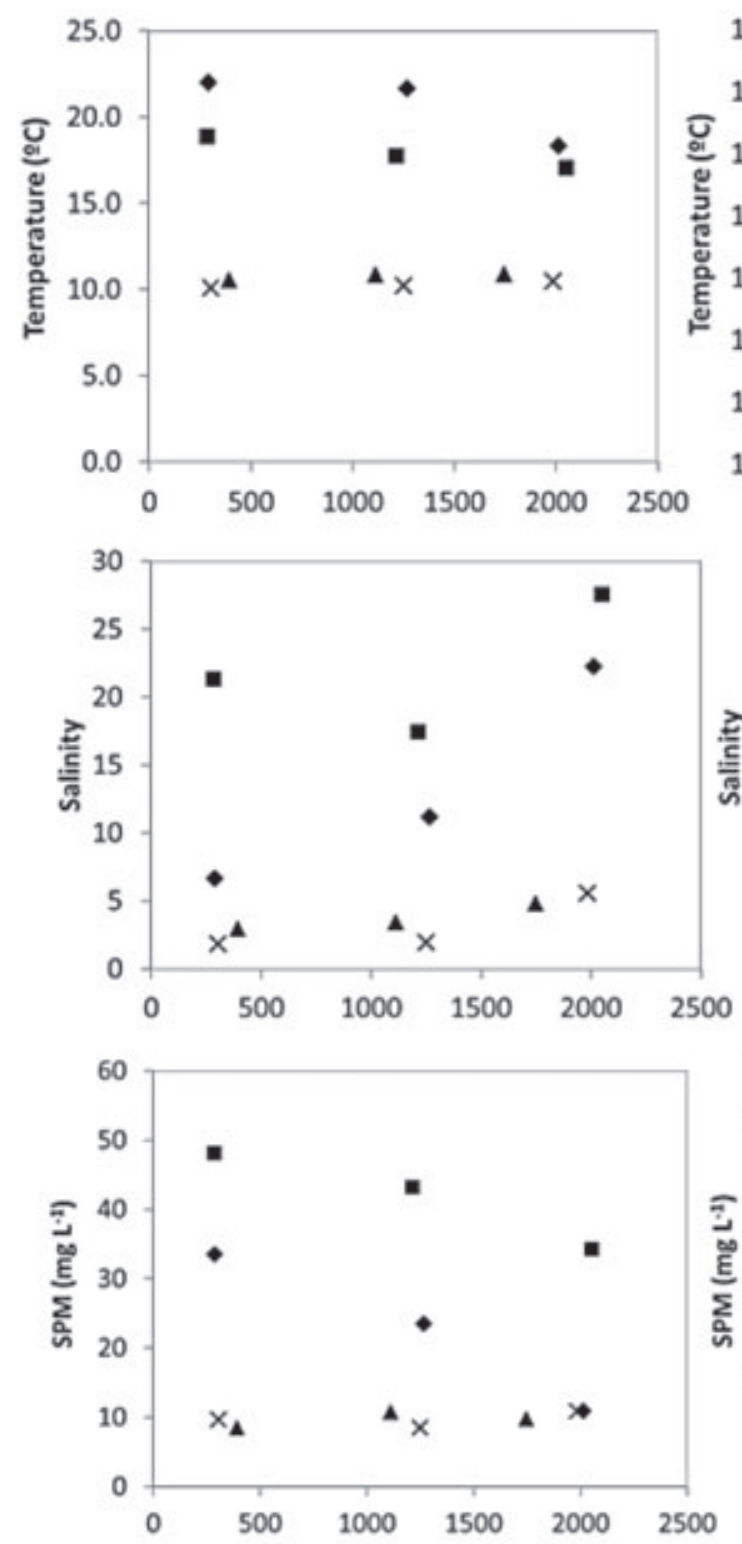

Distance to the upper limit of the estuary (m)
Bottom
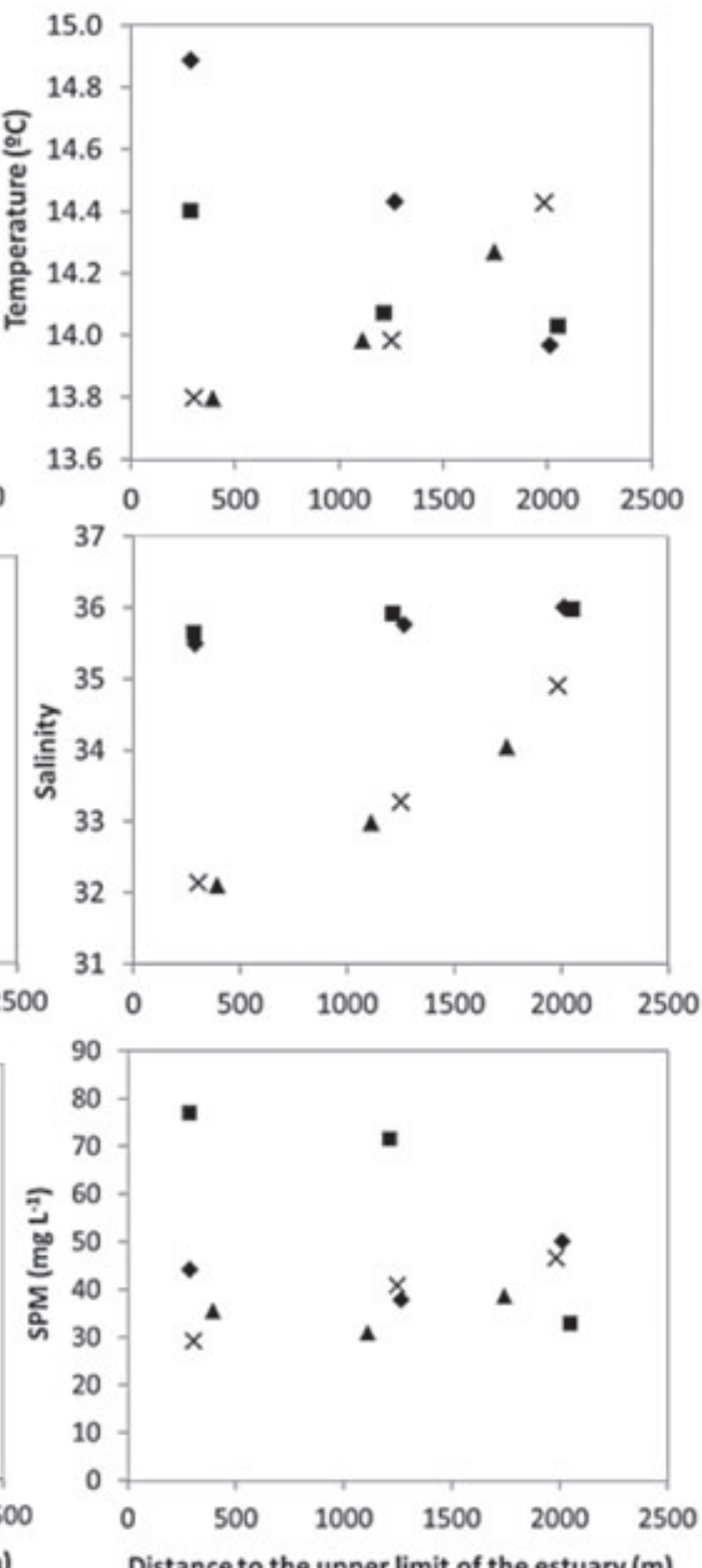

Distance to the upper limit of the estuary $(\mathrm{m})$

summer 2011 - Ebb

summer 2011 - Flood

A winter 2011/12 - Ebb

$\times$ winter 2011/12 - Flood

Figure 2. Longitudinal variation of surface and bottom temperature (T), salinity (S) and suspended particulate matter (SPM) in summer and winter during the two surveys conducted along the Ave estuary. Variación longitudinal en la superficie y en el fondo de la temperatura (T), salinidad (S) y materia particulada en suspensión (SPM), en verano e invierno, durante los 2 muestreos en el estuario del Ave. 

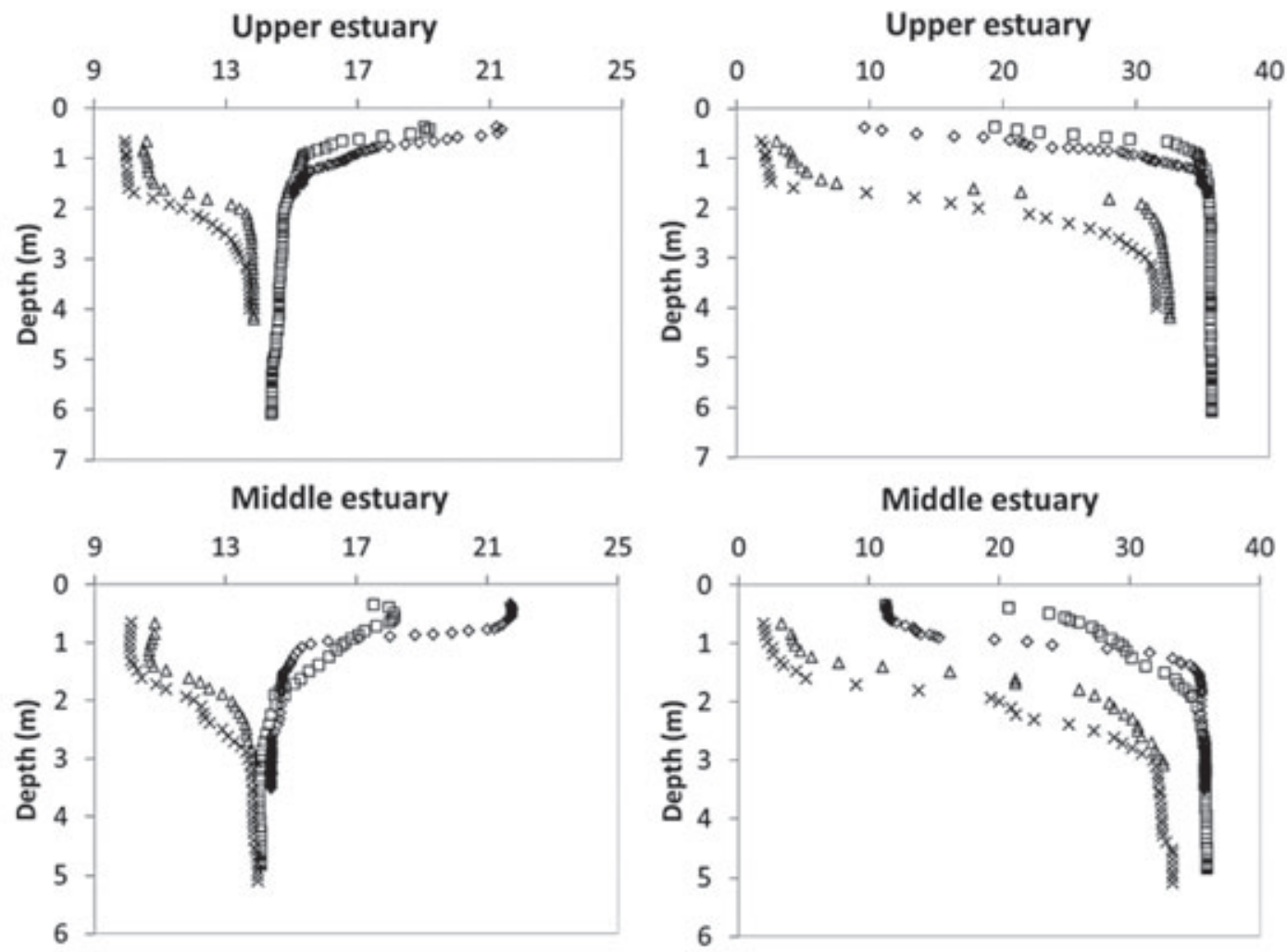

Estuarine mouth

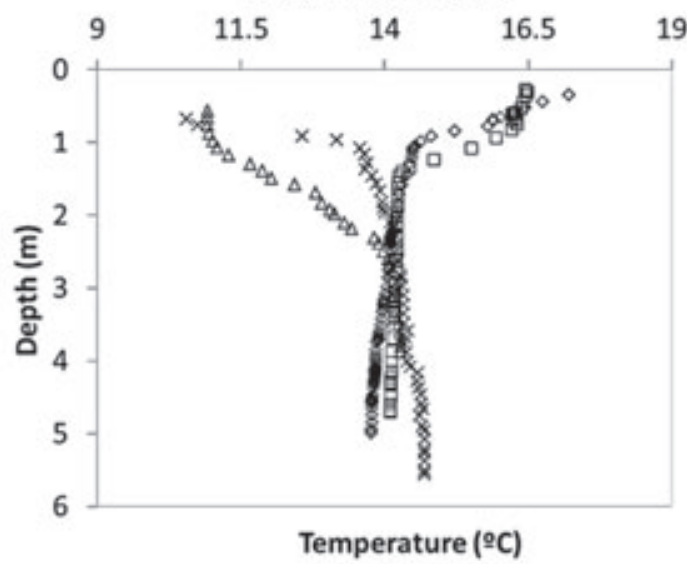

\section{Estuarine mouth}

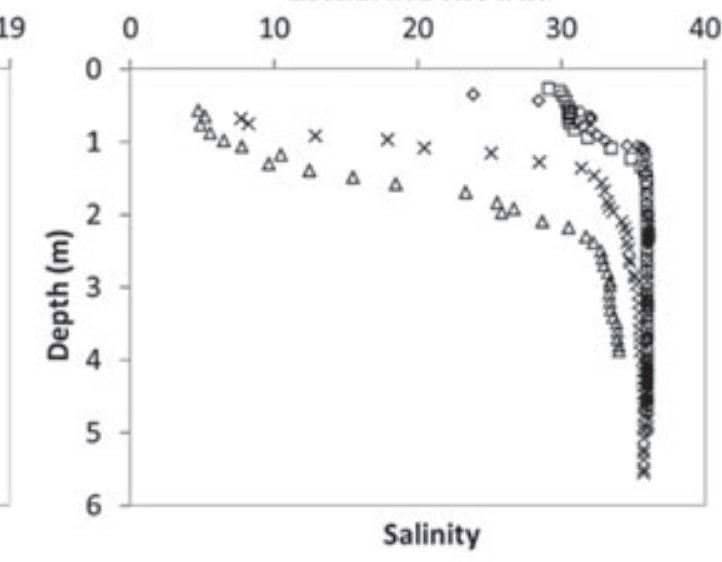

$$
\begin{aligned}
& \diamond \text { summer } 2011 \text { - Ebb } \\
& \square \text { summer } 2011 \text { - Flood } \\
& \triangle \text { winter } 2011 / 12 \text { - Ebb } \\
& \times \text { winter } 2011 / 12 \text { - Flood }
\end{aligned}
$$

Figure 3. Thermoclines and haloclines observed in the three sections of the Ave estuary. Termoclinas y haloclinas en las tres secciones del estuario del Ave. 
Table 1. Sampling dates and ranges of hydrologic and meteorological data for each sampling period in the Ave estuary. $u_{10}$ represents Ave River wind speed referenced to a height of $10 \mathrm{~m}$. Fechas de muestreo y rangos de datos hidrológicos y meteorológicos para cada período de muestreo en el estuario del Ave. Q representa el flujo del río Ave y $\mathrm{u}_{10}$ la velocidad del viento referenciada a una altura de $10 \mathrm{~m}$.

\begin{tabular}{|c|c|c|c|c|c|c|c|}
\hline Season & $\begin{array}{c}\text { Sampling } \\
\text { Dates }\end{array}$ & $\begin{array}{l}\text { Number of } \\
\text { samples }\end{array}$ & $\begin{array}{l}\text { Tidal } \\
\text { current }\end{array}$ & Tide & $\begin{array}{c}\text { Tidal } \\
\text { amplitude (m) }\end{array}$ & $\begin{array}{c}\text { Flow }_{\text {surface }}^{a} \\
\left(\mathrm{~m}^{3} \mathrm{~s}^{-1}\right)\end{array}$ & $\begin{array}{c}u_{10}^{b} \\
\left(\mathrm{~m} \mathrm{~s}^{-1}\right)\end{array}$ \\
\hline Summer & 19 July 2011 & $\begin{array}{l}6 \\
6\end{array}$ & $\begin{array}{l}\text { Ebb } \\
\text { Flood }\end{array}$ & Between spring and neap & 2.4 & 8.5 & $\begin{array}{l}1.1 \\
1.1\end{array}$ \\
\hline Winter & 19 January 2012 & $\begin{array}{l}6 \\
6\end{array}$ & $\begin{array}{c}\text { Ebb } \\
\text { Flood }\end{array}$ & Between spring and neap & 1.7 & 45.2 & $\begin{array}{l}0.5 \\
2.6\end{array}$ \\
\hline
\end{tabular}

A three-way ANOVA was used to test the effects of time of sampling (winter vs. summer), tide (ebb vs. flood) and local (upper, middle and lower estuary) on $\mathrm{CO}_{2}$ fluxes across the air-water interface. SPSS Statistics Version 21 software was used for this analysis. Different ANOVAs were performed with the fluxes obtained using the four different transfer velocity formulations described in the previous paragraph.

\section{RESULTS}

The results presented in Figure 2 show that temperature decreased towards the sea during summer, whereas the opposite trend was observed in winter. At the bottom, temperature varies less than $1{ }^{\circ} \mathrm{C}$. Surface salinity decreased from the sea towards the upper estuary, and the lowest values were observed in winter. At the bottom, salinity varied very little. In winter, it decreases towards the river, as expected. The distribution of suspended particulate matter (SPM) along the estuary does not show a well-defined pattern. However, SPM tends to decrease towards the sea in summer (Fig. 2).

The water column was always stratified, with a marked thermocline and halocline at similar depths throughout the estuary. The thermocline was reversed from summer to winter. In summer, the halocline was shallower (approximately $1 \mathrm{~m}$ depth) than in winter (approximately $2 \mathrm{~m}$ depth) (Fig. 3).

The surface waters were always well oxygenated, with values above $75 \%$ of saturation (Table 2). Lower values were observed at the bottom (Table 3 and Fig. 4), perhaps due to the oxidation of organic matter. The analysis of chlorophyll (a proxy for phytoplankton biomass) showed a maximum value of $9.8 \mu \mathrm{g}^{-1}$ in summer and a minimum value of $3.0 \mu \mathrm{g} \mathrm{l}^{-1}$ in winter (Fig. 4, Table 2).

TA showed the same type of behaviour observed for DIC (Fig. 4). In summer, both during the ebb and the flood, the values obtained for these variables were always higher than in winter. In summer, the DIC surface and bottom values differed less than in winter (Table 2 and 3 ) (Fig. 4). DIC values were generally lower in the fluvial zone (1783 to $2183 \mu \mathrm{mol} \mathrm{kg} \mathrm{kg}^{-1}$ in summer and 751 to $833 \mu \mathrm{mol} \mathrm{kg} \mathrm{kg}^{-1}$ in winter) than in the marine zone (1903 to $2423 \mu \mathrm{mol} \mathrm{kg} \mathrm{kg}^{-1}$ in summer and 853 to $963 \mu \mathrm{mol} \mathrm{kg} \mathrm{kg}^{-1}$ in winter), indicating the presence of DIC sources within the estuary or the introduction of oceanic waters enriched in DIC (Fig. 5).

The $\mathrm{pCO}_{2}$ values of the surface waters varied between 530 and $1694 \mu \mathrm{atm}$, with higher values recorded during the ebb in summer. The lowest values occurred in summer during the flood (Fig. 4, Table 2). $\mathrm{pCO}_{2}$ was higher in the upper section of the estuary and decreased towards the mouth (Fig. 5).

As stated above, the magnitude of the $\mathrm{CO}_{2}$ fluxes emitted from the Ave estuary differs depending on the gas transfer velocity used. As shown by Table 4 and Figure 5, surface waters were always oversaturated in $\mathrm{CO}_{2}$ relative to the atmosphere $\left(\mathrm{pCO}_{2}\right.$, air $\left.\approx 380 \mu \mathrm{atm}\right)$, in contrast to surface water in the estuarine plume and the coastal zone (approximately 4-5 km offshore), 
Surface
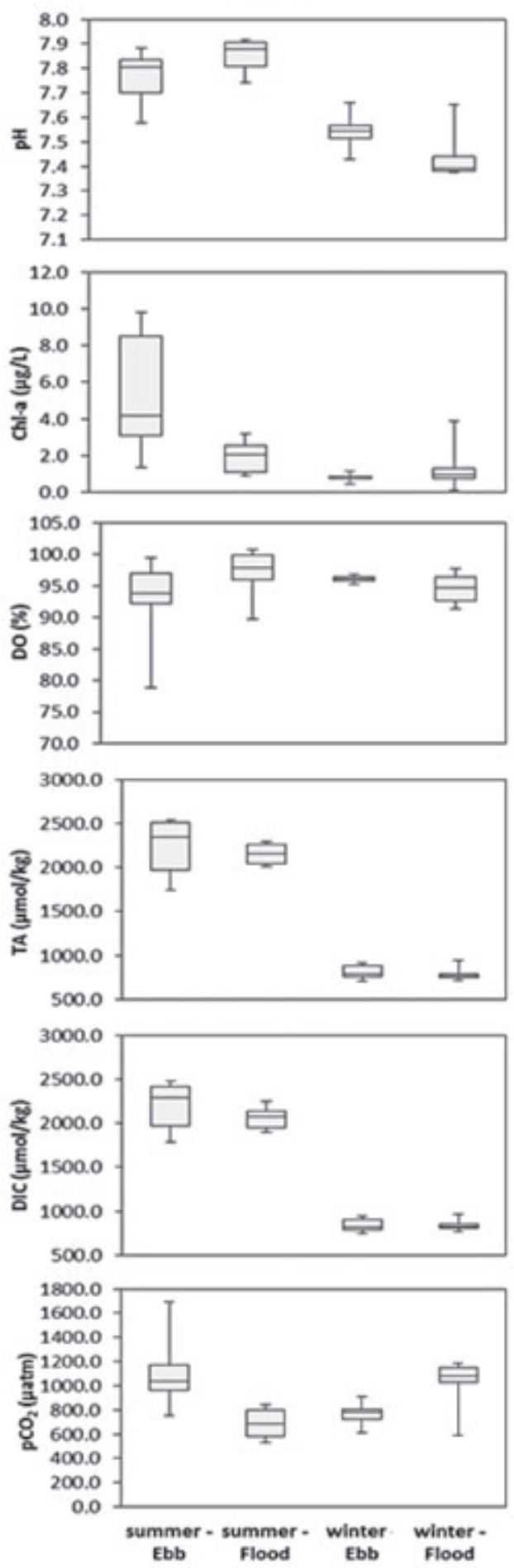

Bottom
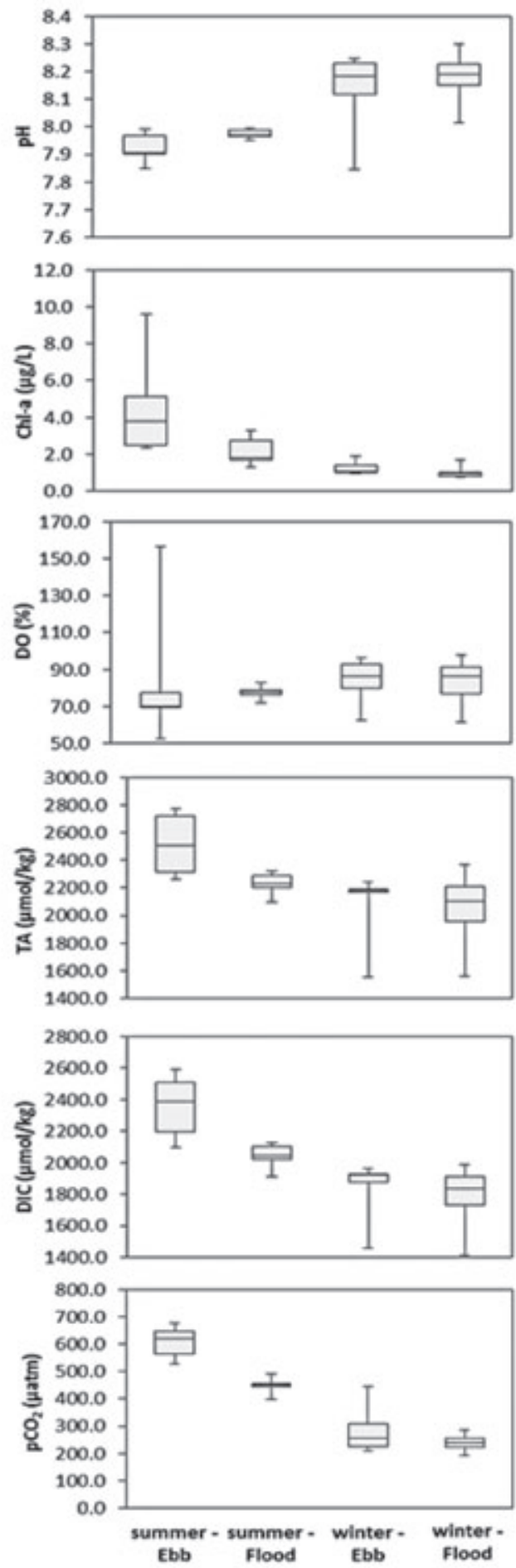

Figure 4. Box-Whisker plot of $\mathrm{pH}$, chlorophyll $a(\mathrm{Chl} a)$, dissolved oxygen (DO), total alkalinity (TA), dissolved inorganic carbon (DIC) and $\mathrm{CO}_{2}$ partial pressure $\left(\mathrm{pCO}_{2}\right)$ in the Ave estuary. Diagramas de caja de $\mathrm{pH}$, clorofila a (Chl a), oxígeno disuelto (DO), alcalinidad total (TA), carbono inorgánico disuelto (DIC) y la presión parcial de $\mathrm{CO}_{2}\left(\mathrm{pCO}_{2}\right)$ en el estuario del Ave. 
Surface
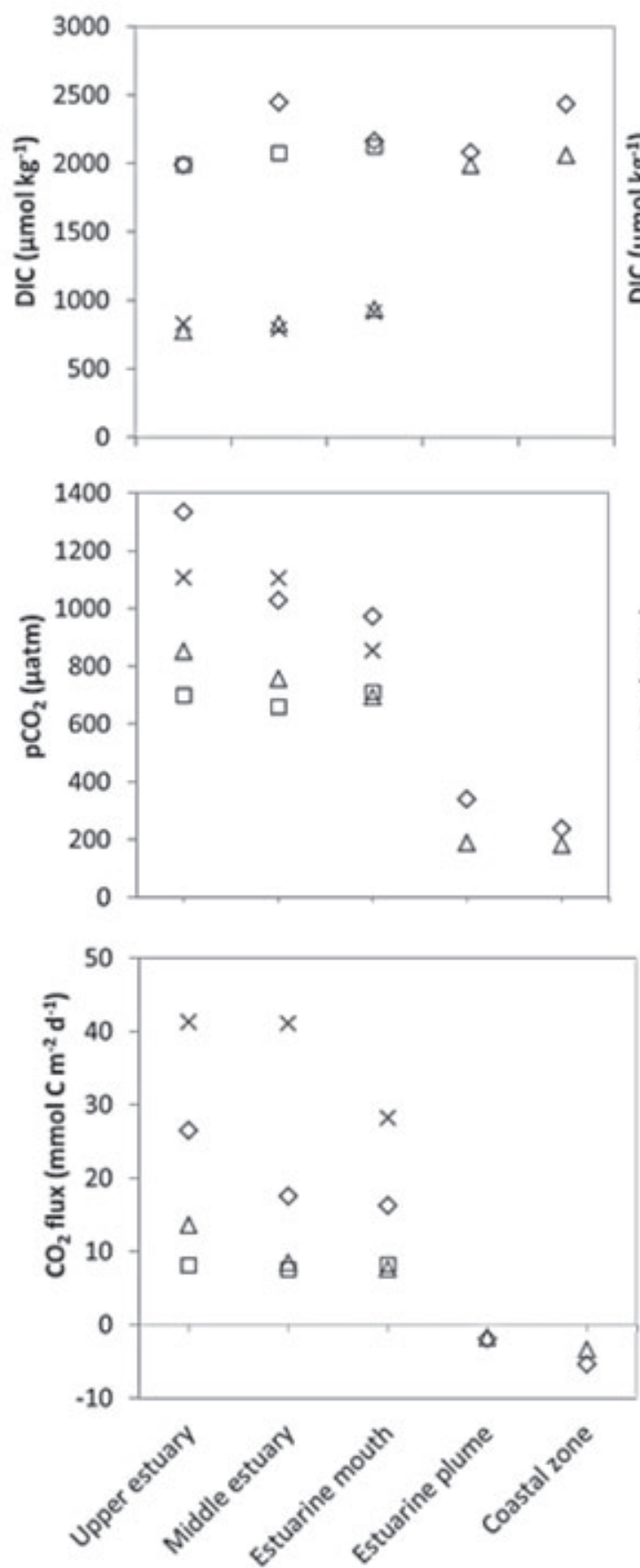

\section{Bottom}
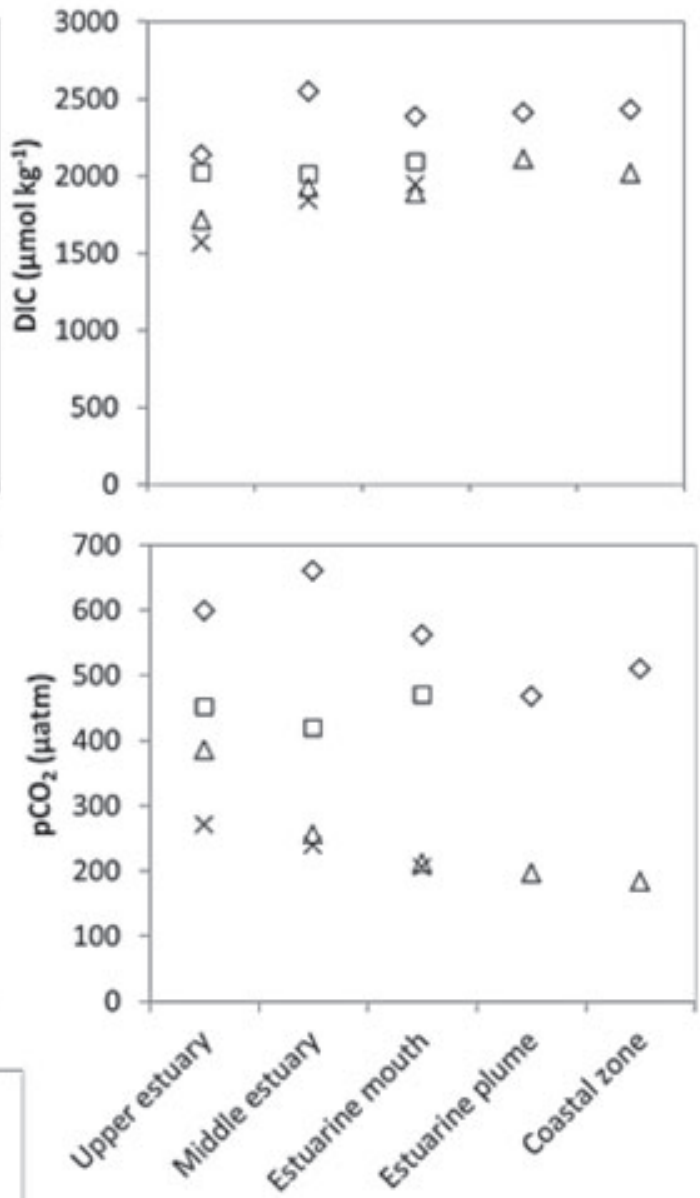

$\diamond$ summer 2011 - Ebb

口 summer 2011 - Flood

$\Delta$ winter $2011 / 12$ - Ebb

$\times$ winter $2011 / 12$ - Flood

Figure 5. Longitudinal distributions of surface and bottom dissolved inorganic carbon (DIC), $\mathrm{CO}_{2}$ partial pressure ( $\left.\mathrm{pCO}_{2}\right)$ and $\mathrm{CO}_{2}$ Fluxes $\left(\mathrm{CO}_{2}\right.$ Flux $)$ in summer and winter during the 2 surveys conducted along the Ave estuary. Data from the estuarine plume and offshore waters are also included for comparative purposes. Distribuciones longitudinales en la superficie y el fondo del carbono inorgánico disuelto (DIC), presión parcial de $\mathrm{CO}_{2}\left(\mathrm{pCO}_{2}\right)$ y flujos de $\mathrm{CO}_{2}\left(\mathrm{CO}_{2}\right.$ Flux) en verano y en invierno, durante los muestreos en el estuario del Ave. Se incluyen también datos en la pluma del estuario y en el mar para comparar. 
Table 2. Range of physical-chemical and biological properties of surface waters in the Ave estuary for each sampling date. Rango de las propiedades físico-químicas y biológicas de las aguas superficiales en el estuario del Ave para cada fecha de muestreo.

\begin{tabular}{ccccccccccc}
\hline Season & Tide & $\mathrm{S}$ & $\mathrm{T}\left({ }^{\circ} \mathrm{C}\right)$ & $\begin{array}{c}\mathrm{SPM} \\
\left(\mathrm{mg} \mathrm{l}^{-1}\right)\end{array}$ & $\begin{array}{c}\mathrm{Chl} a \\
\left(\mu \mathrm{g} \mathrm{l}^{-1}\right)\end{array}$ & $\mathrm{pH}$ & $\mathrm{OD}(\%)$ & $\begin{array}{c}\mathrm{TA} \\
\left(\mu \mathrm{mol} \mathrm{kg}^{-1}\right)\end{array}$ & $\begin{array}{c}\mathrm{DIC} \\
\left(\mu \mathrm{mol} \mathrm{kg}^{-1}\right)\end{array}$ & $\begin{array}{c}\mathrm{pCO} \\
(\mu \mathrm{atm})\end{array}$ \\
\hline \multirow{2}{*}{ Summer } & Ebb & $3.68-23.90$ & $17.2-22.7$ & $10.5-35.6$ & $1.3-9.8$ & $7.58-7.88$ & $78.8-99.4$ & $1741-2539$ & $1783-2476$ & $751-1694$ \\
& Flood & $11.26-29.12$ & $16.5-19.0$ & $26.0-55.5$ & $0.9-3.2$ & $7.74-7.92$ & $89.8-100.8$ & $2016-2296$ & $1903-2246$ & $530-841$ \\
\hline \multirow{2}{*}{ Winter } & Ebb & $2.93-4.89$ & $10.5-10.9$ & $7.4-12.1$ & $0.5-1.2$ & $7.43-7.66$ & $95.3-96.8$ & $709-916$ & $751-944$ & $611-906$ \\
& Flood & $1.77-7.70$ & $10.0-10.6$ & $7.1-13.1$ & $0.1-3.9$ & $7.38-7.65$ & $91.3-97.7$ & $721-953$ & $773-963$ & $590-1187$ \\
\hline
\end{tabular}

as shown in Figure 5 simply for comparison (Carvalho et al., unpublished data). The values for the four different gas transfer velocities described above (cf.-Methodology-Calculations) and the corresponding $\mathrm{CO}_{2}$ fluxes calculated for each sampling occasion and tide are presented in Table 4. The estimated $\mathrm{CO}_{2}$ fluxes for the Ave ranged from 6 to $34 \mathrm{mmol} \mathrm{C} \mathrm{m} \mathrm{d}^{2}$ in summer and from 13 to $40 \mathrm{mmol} \mathrm{C} \mathrm{m}^{-2} \mathrm{~d}^{-1}$ in winter.

The results obtained with the three-way ANOVAs depended on the gas transfer velocity formulations used. In all cases, there were no significant $(p>0.05)$ synergistic effects between the different combinations of the three independent effects (cf-Methodology-Calculations). This result allowed each factor to be tested separately. In the case of the $k_{C 96}$ formulation (cf. Methodology-Calculations and Table 4), significant effects $(p<0.05)$ were obtained for the time of sampling (winter vs. summer) and the tide (ebb vs. flood) effects. No significant effects were obtained with the $k_{R 00}$ formulation. For the $k_{B 04}$ formulation, significant effects were obtained for the time of sampling. No significant effects were obtained with the $k_{C 96}$ formulation.

\section{DISCUSSION}

The $\mathrm{CO}_{2}$ partial pressure ranged from $\approx 689$ to $\approx 1111 \mu \mathrm{atm}$ in summer during the flood and the ebb, respectively, whereas the winter values ranged from $\approx 767$ to $\approx 1021 \mu$ atm during the ebb and the flood, respectively. The $\mathrm{pCO}_{2}$ values obtained for the Ave estuary are within the range of values recorded for other coastal systems (Chen \& Borges, 2009), although they are lower than the values measured in other Portuguese estuaries such as the Douro, the Tagus and the Sado (Oliveira et al., 2012). These results suggest that the Ave estuary releases $\mathrm{CO}_{2}$ to the atmosphere, consistent with previous observations in other estuaries (e.g., Raymond et al., 2000; Borges, 2011). The results obtained along the Portuguese shore, at the Sado and Tagus estuaries and in the adjacent coastal zones point to a dominance of heterotrophic metabolism and $\mathrm{CO}_{2}$ outgassing, especially in winter, in direct association with river organic loads (Cabeçadas \& Oliveira, 2005; Oliveira et al., 2006). A study of the Douro estuary (Azevedo et al., 2006) has shown heterotrophic metabolism to be dominant.

Table 3. Range of physical, chemical and biological properties of bottom waters in the Ave estuary for each sampling date. Rango de las propiedades físico-químicas y biológicas de las aguas del fondo de estuario del Ave para cada fecha de muestreo.

\begin{tabular}{|c|c|c|c|c|c|c|c|c|c|c|}
\hline Season & Tide & S & $\mathrm{T}\left({ }^{\circ} \mathrm{C}\right)$ & $\begin{array}{c}\text { SPM } \\
\left(\mathrm{mg} \mathrm{l}^{-1}\right)\end{array}$ & $\begin{array}{c}\text { Chl } a \\
\left(\mu g l^{-1}\right)\end{array}$ & $\mathrm{pH}$ & OD (\%) & $\begin{array}{c}\mathrm{TA} \\
\left(\mu \mathrm{mol} \mathrm{kg}{ }^{-1}\right)\end{array}$ & $\begin{array}{c}\text { DIC } \\
\left(\mu \mathrm{mol} \mathrm{kg}{ }^{-1}\right)\end{array}$ & $\begin{array}{l}\mathrm{pCO}_{2} \\
(\mu \mathrm{atm})\end{array}$ \\
\hline \multirow{2}{*}{ Summer } & Ebb & $35.36-36.00$ & $13.8-15.1$ & $25.4-56.2$ & $2.3-5.3$ & 7.85-7.99 & $52.4-83.0$ & $2259-2769$ & 2099-2588 & $527-678$ \\
\hline & Flood & $35.62-35.99$ & $14.0-14.4$ & $24.2-84.7$ & $1.3-3.3$ & 7.95-7.99 & $72.1-83.0$ & 2095-2320 & $1908-2125$ & $399-490$ \\
\hline \multirow{2}{*}{ Winter } & $\mathrm{Ebb}$ & $31.69-34.07$ & $13.7-14.3$ & $26.6-50.8$ & $1.0-1.9$ & $7.84-8.25$ & $62.6-96.3$ & $1552-2240$ & 1460-1965 & $209-446$ \\
\hline & Flood & $31.54-35.77$ & $13.7-14.7$ & $26.0-48.7$ & $0.8-1.7$ & $8.02-8.30$ & $61.7-97.7$ & $1562-2368$ & 1414-1984 & $191-284$ \\
\hline
\end{tabular}


The large uncertainty associated with the gas transfer coefficient prevents an accurate comparison between $\mathrm{CO}_{2}$ flux estimates across the air-water interface obtained in different studies (Raymond \& Cole, 2001). Several authors have previously addressed these uncertainties (Carini et al., 1996; Raymond \& Cole, 2001; Borges et al., 2004b; Abril et al., 2009). The equation obtained by Carini et al. (1996) for the Parker River estuary (USA) is based on wind speed and precipitation. The formulation proposed by Raymond et al. (2000) is based on wind speed. In a later study, Borges et al. (2004a) concluded that a simple parameterisation of $\mathrm{k}$ as a function of wind speed is site specific, related to water turbulence at the air-water interface and to fetch. According to the same authors, this site specificity may lead to substantial errors in flux computations if a generic relationship is employed for the gas transfer velocity as a function of wind speed. Similarly, Borges et al. (2004b) has proposed a formulation based on current velocity, wind speed and depth. More recently,
Abril et al. (2009) concluded that turbidity may also influence gas transfer velocities and proposed a new generic equation as a function of current velocity, wind speed, estuarine surface area and total suspended matter concentration. The results presented in Table 4 for the $\mathrm{CO}_{2}$ gas transfer velocities show a reasonable agreement among all but $k_{B 04}$, described in Borges et al. (2004b), which produced larger estimates than the remaining three formulations. Interestingly, the simpler formulations of Carini et al. (1996) and Raymond et al. (2000) produced results more closely resembling the most sophisticated formulation of Abril et al. (2009), which was validated for estuaries with surface areas less than $500 \mathrm{~km}^{2}$. The estimated $\mathrm{CO}_{2}$ fluxes for the Ave are lower than those observed in other estuaries. For example, the Tagus estuary emits $87 \mathrm{mmol} \mathrm{C} \mathrm{m}^{-2} \mathrm{~d}^{-1}$ in summer and $110 \mathrm{mmol} \mathrm{C}$ $\mathrm{m}^{2} \mathrm{~d}^{1}$ in winter (Oliveira, 2011), and the average $\mathrm{CO}_{2}$ flow rate of inner estuaries studied to date is approximately $84 \mathrm{mmol} \mathrm{C} \mathrm{m}^{-2} \mathrm{~d}^{-1}$ (Borges, 2011). However, these estimates for the Ave

Table 4. Wind speed, carbon dioxide partial pressure $\left(\mathrm{pCO}_{2}\right)$ and its gradient across the air-water interface $\left(\Delta \mathrm{pCO}_{2}\right)$, gas transfer velocities calculated with the formulations mentioned in the text (cf.-Methodology-Calculations) and air-water $\mathrm{CO}_{2}$ fluxes in the Ave estuary for each sampling date, calculated with the different gas transfer velocities ( \pm 1 standard deviation). Velocidad del viento, presión parcial del dióxido de carbono y su gradiente a través de la interfase agua-aire, coeficientes de transferencia de masa, calculados conforme a lo descrito en el texto (cf.-Metodología-Cálculos) y flujos aire-agua de $\mathrm{CO}_{2}$ en estuario del Ave para cada fecha de muestreo, calculados con los diferentes coeficientes de transferencia de masa ( \pm 1 desviación estándar).

\begin{tabular}{|c|c|c|c|c|c|}
\hline & & \multicolumn{2}{|c|}{ Summer } & \multicolumn{2}{|c|}{ Winter } \\
\hline & & Ebb & Flood & Ebb & Flood \\
\hline \multirow{10}{*}{$\begin{array}{l}\text { Water-air } \mathrm{CO}_{2} \text { flux } \\
\left(\mathrm{mmol} \mathrm{Cm} \mathrm{Cm}^{-2} \mathrm{~d}^{-1}\right)\end{array}$} & Wind speed $\left(\mathrm{m} \mathrm{s}^{-1}\right)$ & 1.08 & 1.08 & 0.51 & 2.57 \\
\hline & $\mathrm{pCO}_{2, \text { water }}(\mu \mathrm{atm})$ & $1111 \pm 322$ & $689 \pm 137$ & $767 \pm 100$ & $1021 \pm 220$ \\
\hline & $\Delta \mathrm{pCO}_{2}(\mu \mathrm{atm})$ & $729 \pm 323$ & $307 \pm 137$ & $370 \pm 96$ & $624 \pm 216$ \\
\hline & $k_{C 96}\left(\mathrm{~cm} \mathrm{~h}^{-1}\right)$ & $2.3 \pm 0.1$ & $2.1 \pm 0.1$ & $4.2 \pm 0.0$ & $1.7 \pm 0.0$ \\
\hline & $k_{R 00}\left(\mathrm{~cm} \mathrm{~h}^{-1}\right)$ & $3.1 \pm 0.2$ & $2.8 \pm 0.1$ & $3.5 \pm 0.0$ & $2.3 \pm 0.0$ \\
\hline & $k_{B 04}\left(\mathrm{~cm} \mathrm{~h}^{-1}\right)$ & $5.2 \pm 0.4$ & $4.6 \pm 0.2$ & $8.5 \pm 1.5$ & $5.3 \pm 0.7$ \\
\hline & $k_{A 09}\left(\mathrm{~cm} \mathrm{~h}^{-1}\right)$ & $2.5 \pm 0.0$ & $2.4 \pm 0.0$ & $3.1 \pm 0.0$ & $2.3 \pm 0.0$ \\
\hline & $k_{C 96}\left(\mathrm{~cm} \mathrm{~h}^{-1}\right)($ Carini et al., 1996) & $14.7 \pm 6.8$ & $5.9 \pm 2.7$ & $18.9 \pm 5.0$ & $13.1 \pm 4.6$ \\
\hline & $k_{R 00}\left(\mathrm{~cm} \mathrm{~h}^{-1}\right)($ Raymond et al., 2000) & $19.8 \pm 9.3$ & $7.8 \pm 3.6$ & $16.0 \pm 4.2$ & $17.9 \pm 6.3$ \\
\hline & $k_{B 04}\left(\mathrm{~cm} \mathrm{~h}^{-1}\right)($ Borges et al., 2004b) & $33.7 \pm 15.6$ & $12.7 \pm 5.6$ & $39.7 \pm 17.0$ & $42.3 \pm 16.8$ \\
\hline & $k_{A 09}\left(\mathrm{~cm} \mathrm{~h}^{-1}\right)($ Abril et al., 2009) & $16.0 \pm 7.1$ & $6.8 \pm 3.1$ & $14.1 \pm 3.7$ & $18.2 \pm 6.4$ \\
\hline
\end{tabular}

Note: In summer, the atmospheric concentration of $\mathrm{CO}_{2}$ was not measured. Therefore, values were obtained from the Terceira Island reference station (Azores, Portugal, 38 46 ${ }^{\prime}$ N 27 $23^{\prime} \mathrm{W}$ ), a component of the network of the National Oceanic and Atmospheric Administration (NOAA)/Climate Monitoring and Diagnostics Laboratory/Carbon Cycle Greenhouse Gases Group (Conway et al., 2012). The latest available values from July 2008 were used. There are no data after this year for July. 
are based on only two sampling campaigns. Therefore, any comparison with other systems must be made with caution.

The results of the present study suggest that river water is not a source of DIC to the estuary. However, its $\mathrm{CO}_{2}$ partial pressure is higher than that of sea water, for estuarine surface water. Therefore, $\mathrm{CO}_{2}$ outgassing is greater in the upper reaches of the estuary, and the results of the current study are consistent with Borges et al. (2006), who stated that the contribution of river water to the overall estuarine $\mathrm{CO}_{2}$ emissions is greater in estuaries with a short freshwater residence time. According to Borges (2011), the estimate of $\mathrm{CO}_{2}$ emissions from estuaries is in reasonable agreement with the input of river $\mathrm{CO}_{2}$ and particulate organic matter degradation during estuarine transit. The small size of the Ave estuary and the low water residence time may act to make its emissions more directly dependent on river inputs and less dependent on local organic matter degradation. Estuarine bottom waters, as well as offshore waters, had a lower $\mathrm{CO}_{2}$ content, confirming the $\mathrm{CO}_{2}$ dilution role of sea water within the estuarine ecosystem. DIC and $\mathrm{pCO}_{2}$ exhibit a different pattern, with the former showing similar values along the estuary and in the sea in summer but not in winter, when it increases in the estuarine plume and the coastal zone, and the latter decreasing towards the sea in surface waters. These differences may be explained by the higher abundance of carbonate species at the bottom, within the salt wedge, and towards the sea, outweighing lower $\mathrm{pCO}_{2}$ levels in the DIC estimates. This large spatial variability in DIC and $\mathrm{pCO}_{2}$, typically observed in estuaries, led Borges (2011) to state that issues of adequate spatial and temporal coverage are more critical in estuaries than in other coastal ecosystems.

The results of the three-way ANOVA described above (cf.-Methodology-Calculations and Results section) did not permit a clear conclusion about several of the tested effects because of their dependence on the gas transfer velocity formulations employed. However, differences between winter and summer results and between ebb and flood tides may be significant depending on the formulations used. Spatial differences along the estuary never showed significant results.

Typically, the sink/source role of aquatic ecosystems is assessed as in this study - through estimates of $\mathrm{CO}_{2}$ fluxes across the air-water interface. Generally, the direction of the $\mathrm{CO}_{2}$ flux is the criteria to evaluate the mentioned role. However, this approach may not be ideal because the outgassing of $\mathrm{CO}_{2}$ should not be equated with a source role. An ecosystem should be considered a net $\mathrm{CO}_{2}$ source if it mobilises carbon that was otherwise "hidden" from the carbon biogeochemical cycle. This process would correspond to a real increase in atmospheric $\mathrm{CO}_{2}$ because, just as in the burning of fossil fuels, "new" carbon would be added to the corresponding biogeochemical cycle. According to these ideas, the determination of the sink/source role of aquatic ecosystems would require the calculation of the entire carbon budget of the ecosystem.

To summarize, the results presented in this work are consistent with the findings of other studies, with estuarine waters outgassing $\mathrm{CO}_{2}$ to the atmosphere. The principal contribution to this outgassing is made by river waters. Because the estuarine plume and the outer areas of the sea are undersaturated, they act as $\mathrm{CO}_{2}$ importers from the atmosphere. As discussed above, the direction of $\mathrm{CO}_{2}$ fluxes may not be a good proxy for the sink/source $\mathrm{CO}_{2}$ role of these ecosystems, and it is important to improve the way in which this role is assessed to ensure that our perceptions are closer to reality. The results obtained suggest a greater temporal than spatial variability in the outgassing processes.

\section{ACKNOWLEDGEMENTS}

The authors wish to thank the Vila do Conde Municipality and "Centro de Monitorização e Interpretação Ambiental” (CMIA) of Vila do Conde for their help and for providing access to the laboratory facilities at CMIA. 


\section{REFERENCES}

ABRIL, G., H. ETCHEBER, A. V. BORGES, M. FRANKIGNOULLE, 2000. Excess atmospheric carbon dioxide transported by rivers into the Scheldt estuary. Earth and Planetary Science Letter, 330 (11): 761-768, DOI:10.1016/S12518050(00)00231-7.

ABRIL, G. \& A. V. BORGES. 2004. Carbon dioxide and methane emissions from estuaries. In: Greenhouse gases emissions from natural environments and hydroelectric reservoirs: fluxes and processes. A. Tremblay, L. Varfalvy, C. Roehm \& M. Garneau (eds): 187-207. Environmental Science Series, Springer, Berlin, Heidelberg, New York.

ABRIL, G., M. V. COMMARIEU, A. SOTTOLICHIO, P. BRETEL \& F. GUÉRIN. 2009. Turbidity limits gas exchange in a large macrotidal estuary. Estuarine, Coastal and Shelf Science, 83: 342-348.

AZEVEDO, I. C., P. DUARTE \& A. A. BORDALO. 2006. Pelagic metabolism of the Douro estuary (Portugal)-Factors controlling primary production. Estuarine, Coastal and Shelf Science, 69: 133146.

BORGES, A. V. \& M. FRANKIGNOULLE. 2002. Distribution of surface carbon dioxide and air-sea exchange in the upwelling system off the Galician coast. Global Biogeochemical Cycles, 16(2), 1020, DOI: 10.1029/2000GB001385.

BORGES, A. V., S. DJENIDI, G. LACROIX, J. THÉATE, B. DELILLE \& M. FRANKIGNOULLE. 2003. Atmospheric $\mathrm{CO}_{2}$ flux from mangrove surrounding waters. Geophysical Research Letters, 30(11): 1558. DOI:10.1029/2003GL017 143.

BORGES, A. V., B. DELILLE \& L. S. SCHIETTECATTE. 2004a. Gas transfer velocities of $\mathrm{CO}_{2}$ in three European estuaries (Randers Fjord, Scheldt, and Thames). Limnology and Oceanography, 49(5): 1630-1641.

BORGES, A. V., J. P. VANDERBORGHT, L. S. SCHIETTECATTE, F. GAZEAU, S. FERRÓNSMITH, B. DELILLE \& M. FRANKIGNOULLE. 2004b. Variability of the gas transfer velocity of $\mathrm{CO}_{2}$ in a macrotidal estuary (the Scheldt). Estuaries, 27(4): 593-603.

BORGES, A. V. 2005. Do we have enough pieces of the jigsaw to integrate $\mathrm{CO}_{2}$ fluxes in the coastal ocean? Estuaries, 28(1): 3-27.
BORGES, A. V., B. DELILLE \& M. FRANKIGNOULLE. 2005. Budgeting sinks and sources of $\mathrm{CO}_{2}$ in the coastal ocean: Diversity of ecosystems counts. Geophysical Research Letters, 32, L14601, DOI:10.1029/2005GL023053.

BORGES, A. V., L. S. SCHIETTECATTE, G. ABRIL, B. DELILE \& F. GAZEAU. 2006. Carbon dioxide in European coastal waters. Estuarine Coastal and Shelf Science, 70(3): 375-387.

BORGES, A. V. \& G. ABRIL. 2011. Carbon Dioxide and Methane Dynamics in Estuaries. In: Treatise on Estuarine and Coastal Science. E. Wolanski and DS McLusky (eds.): 119-161. Waltham: Academic Press.

BORGES, A. V. 2011. Present Day Carbon Dioxide Fluxes in the Coastal Ocean and Possible Feedbacks Under Global Change. 47-77. In: Oceans and the atmospheric carbon content. P. Duarte, \& J.M. Santana-Casiano. Springer. DOI: 10.1007/ 978-90-481-9821-4_3.

BOZEC, Y., H. THOMAS, K. ELKALAY \& H. DE BAAR. 2005. The continental shelf pump for $\mathrm{CO}_{2}$ in the North Sea-evidence from summer observations. Marine Chemistry, 93 (2-4): 131-147.

CABEÇADAS, L. \& A. P. OLIVEIRA. 2005. Impact of a Coccolithus braarudii bloom on the carbonate system of Portuguese coastal waters. Journal of Nannoplankton Research, 27(2): 141-147.

CAI, W. J. \& M. DAI. 2004. Comment on "Enhanced Open Ocean Storage of $\mathrm{CO}_{2}$ from Shelf Sea Pumping". Science, 306(5701): 1477.

CAI, W. J., M. DAI \& Y. WANG. 2006. Air-sea exchange of carbon dioxide in ocean margins: A province-based synthesis. Geophysical Research Letters, 33: L12603, DOI:10.1029/2006GL0262 19.

CARINI, S., N. WESTON, C. HOPKINSON, J. TUCKER, A. GIBLIN \& J. VALLINO. 1996. Gas exchange rates in the Parker River estuary. Massachusetts. Biological Bulletin, 191: 333-334.

CARVALHO, R., N. BARROS \& P. DUARTE. 2011. Impact of Oporto metropolitan area carbon dioxide emissions over the adjacent coastal zone. In: Oceans and the atmospheric carbon content. P. Duarte, \& J. M. Santana-Casiano: 23-46. Springer. DOI: 10.1007/978-90-481-9821-4_2.

CHEN, C. T. A. \& A. V. BORGES. 2009. Reconciling opposing views on carbon cycling in the coastal ocean: continental shelves as sinks and nearshore ecosystems as sources of atmospheric $\mathrm{CO}_{2}$. Deep- 
Sea Research II, 56 (8-10): 578-590. DOI:10. 1016/j.dsr2.2009.01.001.

CONWAY, T. J., P. M. LANG \& K. A. MASARIE. 2012. Atmospheric Carbon Dioxide Dry Air Mole Fractions from the NOAA ESRL Carbon Cycle Cooperative Global Air Sampling Network, 19682011, Version: 2012-08-15, ftp://ftp.cmdl.noaa. gov/ccg/co2/flask/month/.

DICKSON, A. G., C. L. SABINE \& J. R. CHRISTIAN. 2007. Guide to best practices for ocean $\mathrm{CO}_{2}$ measurements. PICES Special Publication, 3.

FILGUEIRA, R., J. FERNÁNDEZ-REIRIZ \& U. LABARTA. 2009. Clearance rate of the mussel Mytilus galloprovincialis. I. Response to extreme chlorophyll values. Ciencias Marinas, 35 (4): 405-417.

FRANKIGNOULLE, M., G. ABRIL, A. BORGES, I. BOURGE, C. CANON, B. DELILLE, E. LIBERT \& J. M. THÉATE. 1998. Carbon dioxide emission from European estuaries. Science, 282: 434-436.

GATTUSO, J. P., M. FRANKIGNOULLE \& R. WOLLAST. 1998. Carbon and carbonate metabolism in coastal aquatic ecosystems. Annual Review of Ecology and Systematics, 29: 405-434. DOI: 10.1146/ANNUREV.ECOLSYS.29.1.405.

GAZEAU, F., B. GENTILI, S. V. SMITH, M. FRANKIGNOULLE \& J. P. GATTUSO. 2004. The European coastal zone: characterization and first assessment of ecosystem metabolism. Estuarine, Coastal and Shelf Science, 60 (4): 673-694.

HO, D. T., P. SCHLOSSER \& P. M. ORTON. 2011. On Factors Controlling Air-Water Gas Exchange in a Large Tidal River. Estuaries and Coasts, 34 (6): 1103-1116.

HIDROGRÁFICO. 2011. Tabela de Marés: Previsão de Marés-Leixões: http://www.hidrografico.pt/previsao-mares-leixoes.php.

KETCHUM, B. H. 1983. Estuarine characteristics. In: Estuaries and Enclosed Seas. B. H. Ketchum (ed.). Elsevier, Amsterdam.

KONÉ, Y. J. M., G. ABRIL, K. N. KOUADIO, B. DELILLE \& A. V. BORGES. 2009. Seasonal variability of carbon dioxide in the rivers and lagoons of Ivory Coast (West Africa). Estuaries and Coasts, 32: 246-260.

KREMER, J. N., A. REISCHAUER \& C. D'AVANZO. 2003. Estuary-specific variation in the airwater gas exchange coefficient for oxygen. Estuaries, 26: 829-836.
LARUELlE, G. G., H. H. DÜRR, C. P. SLOMP \& A. V. BORGES. 2010. Evaluation of sinks and sources of $\mathrm{CO}_{2}$ in the global coastal ocean using a spatially-explicit typology of estuaries and continental shelves. Geophysical Research Letters, 37, L15607, DOI: 10.1029/2010GL043691.

MACKENZIE, F. T., A. LERMAN \& A. J. ANDERSSON. 2004. Past and present of sediment and carbon biogeochemical cycling models. Biogeosciences, 1: 11-32.

MARINO, R. \& R. W. HOWARTH. 1993. Atmospheric oxygen exchange in the Hudson river: Dome measurements and comparison with other natural waters. Estuaries, 16 (3): 433-445.

MEYBECK, M. 1993. Riverine transport of atmospheric carbon: sources, global typology and budget. Water Air Soil Pollution, 70: 443-463.

MILLERO, F. J., T. B. GRAHAM, F. HUANG, H. BUSTOS-SERRANO \& D. PIERROT. 2006. Dissociation constants of carbonic acid in sea water as a function of salinity and temperature. Marine Chemistry, 100 (1-2): 80-94.

OLIVEIRA, A. P. 2011. Fluxos de $\mathrm{CO}_{2}$ na interface ar-água num sistema estuarino português e zona costeira adjacente. Ph.D. Thesis. Universidade Técnica de Lisboa, Instituto Superior Técnico, Lisboa.

OLIVEIRA, A. P., M. NOGUEIRA \& G. CABEÇADAS. 2006. $\mathrm{CO}_{2}$ variability in surface coastal waters adjacent to the Tagus Estuary (Portugal). Ciencias Marinas, 32 (2B): 401-411.

OLIVEIRA, A. P., G. CABEÇADAS \& T. PILARFONSECA. 2012. Iberia Coastal Ocean in the $\mathrm{CO}_{2}$ Sink/Source Context: Portugal Case Study. Journal of Coastal Research, 28 (1): 184-195.

ORR, J. C., E. MAIER-REIMER, U. MIKOLAJEWICZ, P. MONFRAY, J. L. SARMIENTO, J. R. TOGGWEILER, N. K. TAYLOR, J. PALMER, N. GRUBER, C. L. SABINE, C. LE QUE'RE', R. M. KEY \& J. BOUTIN. 2001. Estimates of anthropogenic carbon uptake from four threedimensional global ocean models. Global Biogeochemical Cycles, 15 (1): 43-60.

ORR, J. C., V. J. FABRY, O. AUMONT, L. BOPP, S. C. DONEY, R. A. FEELY, A. GNANADESIKAN, N. GRUBER, A. ISHIDA, F. JOOS, R.M. KEY, K. LINDSAY, E. MAIER-REIMER, R. MATEAR, P. MONFRAY, A. MOUCHET, R.G. NAJJAR, G.-K. PLATTNER, K. B. RODGERS, C. L. SABINE, J. L. SARMIENTO, R. SCHLITZER, R. D. SLATER, I. J. TOTTERDELL, M. F. WEIRIG, Y. 
YAMANAKA \& A. YOOL. 2005. Anthropogenic ocean acidification over the twenty-first century and its impact on calcifying organisms. Nature, 437 (7059): 681.

PERILLO, G. M. E. 1995. Definition and geomorphologic classifications of estuaries. In: Geomorphology and Sedimentology of Estuaries, Developments in Sedimentology. G. M. E. Perillo, (ed.): 17-47. Elsevier, Amsterdam.

PRITCHARD, D. W. 1967. Observations of circulation in coastal plain estuaries. In: Estuaries. G.H. Lauff, (ed.): 37-44. American Association for the Advancement of Science, Washington.

RAYMOND, P. A., J. E. BAUER \& J. J. COLE. 2000. Atmospheric $\mathrm{CO}_{2}$ evasion, dissolved inorganic carbon production, and net heterotrophy in the York River estuary. Limnology Oceanography, 45 (8): 1707-1717

RAYMOND, P. A. \& J. J. COLE. 2001. Gas exchange in rivers and estuaries: Choosing a gas transfer velocity. Estuaries, 24 (2): 312-317, DOI:10.23 07/1352954.

SNIRH. 2011. Sistema Nacional de Informação de Recursos Hídricos: http://snhir.pt.

THOMAS, H., M. H. ENGLAND \& V. ITTEKKOT. 2001. An off-line 3D model of anthropogenic $\mathrm{CO}_{2}$ uptake by the oceans. Geophysical Research Letters 28 (3): 547-550.

THOMAS, H., Y. BOZEC, K. ELKALAY \& H. DE BAAR. 2004. Enhanced Open Ocean Storage of $\mathrm{CO}_{2}$ from Shelf Sea Pumping. Science, 304 (5673): 1005-1008.

THOMAS, H., L. S. SCHIETTECATTE, K. SUY-
KENS, Y. J. M. KONÉ, E. H. SHADWICK, A. E. F. PROWE, Y. BOZEC, H. J. W. DE BAAR \& A. V. BORGES. 2008. Enhanced ocean carbon storage from anaerobic alkalinity generation in coastal sediments. Biogeosciences Discussions, 5: 3575-3591.

TSUNOGAI, S., S. WATANABE \& T. SATO. 1999. Is there a "continental shelf pump" for the absorption of atmospheric $\mathrm{CO}_{2}$ ? Tellus, 51B: 701-712.

WANG, Z. A. \& W. J. CAI. 2004. Carbon dioxide degassing and inorganic carbon export from a marshdominated estuary (the Duplin River): A marsh $\mathrm{CO}_{2}$ pump. Limnolology and Oceanography, 49 (2): 341-354.

WEISS, R. F. 1974. Carbon dioxide in water and seawater: the solubility of a non-ideal gas. Marine Chemistry, 2: 203-215.

WOLLAST, R. 1998. Evaluation and comparison of the global carbon cycle in the coastal zone and in the open ocean. In: The Global Coastal Ocean. K. H. Brink \& A. R. Robinson (eds.): 213-252. John Wiley \& Sons. New York.

ZAPPA, C. J., P.A. RAYMOND, E. A. TERRAY \& W. R. MCGILLIS. 2003. Variation in surface turbulence and the gas transfer velocity over a tidal cycle in a macro-tidal estuary. Estuaries, 26 (6): 1401-1415.

ZAPPA, C. J., W. R. MCGILLIS, P. A. RAYMOND, J. B. EDSON, E. J. HINSTA, H. J. ZEMMELINK, J. W. H. DACEY \& D. T. HO. 2007. Environmental turbulent mixing controls on air-water gas exchange in marine and aquatic systems. Geophysical Research Letters, 34 (10): L10601. DOI: 1029/ 2006GL028790. 
